\title{
Characteristics of Thiamine Uptake by the BeWo Human Trophoblast Cell Line
}

\author{
Elisa Keating, Clara Lemos, Isabel Azevedo and Fátima Martel* \\ Department of Biochemistry (U38-FCT), Faculty of Medicine, University of Porto, 4200-319 Porto, Portugal
}

Received 24 January 2006, Accepted 23 March 2006

Little is known concerning the mechanisms responsible for the transplacental transfer of thiamine. So, the aim of this work was to characterize the placental uptake of thiamine from the maternal circulation, by determining the characteristics of ${ }^{3} \mathrm{H}$-thiamine uptake by a human trophoblast cell line (BeWo). Uptake of ${ }^{3} \mathrm{H}$-thiamine (50$100 \mathrm{nM})$ by BeWo cells was: 1) temperature-dependent and energy-independent; 2) pH-dependent (uptake increased as the extracellular medium $\mathrm{pH}$ decreased); 3) $\mathrm{Na}^{+}$dependent and $\mathrm{Cl}^{-}$-independent; 4) not inhibited by the thiamine structural analogs amprolium, oxythiamine and thiamine pyrophosphate; 5) inhibited by the unrelated organic cations guanidine, $N$-methylnicotinamide, tetraethylammonium, clonidine and cimetidine; 6) inhibited by the organic cation serotonin, and by two selective inhibitors of the serotonin plasmalemmal transporter (hSERT), fluoxetine and desipramine. We conclude that ${ }^{3} \mathrm{H}$-thiamine uptake by BeWo cells seems to occur through a process distinct from thiamine transporter-1 (hThTr-1) and thiamine transporter-2 (hThTr-2). Rather, it seems to involve hSERT. Moreover, chronic (48 h) exposure of cells to caffeine $(1 \mu \mathrm{M})$ stimulated and chronic exposure to xanthohumol and iso-xanthohumol (1 and $0.1 \mu \mathrm{M}$, respectively) inhibited ${ }^{3} \mathrm{H}$-thiamine uptake, these effects being not mediated through modulation of the expression levels of either hThTr-1 or hSERT mRNA.

Keywords: Apical uptake, BeWo cells, Ethanol, Methylxanthines, Polyphenols, Thiamine

*To whom correspondence should be addressed.

Tel: 35122 5513624; Fax: 351225513624

E-mail: fmartel@med.up.pt

\section{Introduction}

Thiamine (vitamin $\mathrm{B}_{1}$ ), a member of the water-soluble vitamin family, is essential for normal cellular functions, growth and development. In its coenzyme form, thiamine pyrophosphate, it plays a critical role in normal carbohydrate metabolism, by participating in the decarboxylation of a-keto acids such as pyruvate and ketoglutarate, and in transketolation (Tanphaichitr, 1999; Rindi and Laforenza, 2000). Thiamine deficiency in humans leads to a variety of clinical abnormalities, including cardiovascular disorders (e.g., peripheral vasodilatation, biventricular myocardial failure, edema, and acute fulminant cardiovascular collapse) and neurological disorders (e.g., confusion, disordered ocular motility and peripheral neuropathy), and occurs in a high percentage of alcoholics, diabetic patients, and patients with thiamine-responsive megaloblastic anemia (TRMA; also known as Rogers syndrome) (Tanphaichitr, 1999).

Thiamine is an organic cation, and as such it must use carrier-mediated mechanisms in order to cross biological membranes. Two plasmalemmal thiamine transporters, hThTr-1 and hThTr-2, belonging to the SLC19A family of transporters were recently cloned. Characteristics of thiamine transport by hThTr-1 and hThTr-2 include: $\mathrm{Na}^{+}$-independence, $\mathrm{pH}$ dependence (with uptake decreasing as the $\mathrm{pH}$ decreases from physiological to acidic), inhibition by thiamine analogs (e.g. amprolium and oxythiamine) and lack of inhibition by unrelated organic cations (e.g. guanidine and cimetidine) (Diaz et al., 1999; Dutta et al., 1999; Fleming et al., 1999; Labav et al., 1999; Eudy et al., 2000).

Thiamine is particularly important during pregnancy, for normal growth and development of the fetus. Because there is an increase in thiamine requirement in this condition, pregnancy may precipitate clinical manifestations in persons with marginal thiamine status. The importance of thiamine during pregnancy is supported by the observation that severe thiamine deficiency in this period results in fetal death, reduced growth, and congenital malformations (WorthingtonRoberts, 1999). Also, thiamine deficiency resulting from 
maternal chronic alcohol abuse may contribute to fetal alcohol syndrome (Levin et al., 1985).

Despite the clinical significance of maternal-to-fetal transfer of thiamine, the mechanisms mediating placental uptake (at the maternal-facing apical membrane of syncytiotrophoblasts) and efflux (at the fetal-facing basolateral membrane of syncytiotrophoblasts) of this vitamin remain very poorly characterized. The two previous works concerning the characterization of thiamine transport at the human placenta level were conducted using two distinct models: the isolated perfused human placenta and human placental brush-border membrane vesicles. Using the first model, it was shown that there is a net transplacental transfer of thiamine towards the fetal compartment, and a concentrative thiamine accumulation in placental tissue (Dancis et al., 1988; Schenker et al., 1990). On the other hand, using human placental brush border membrane vesicles, some characteristics of the transport of thiamine were determined (e.g. its $\mathrm{Na}^{+}-$and proton-dependence) (Grassl, 1998).

Because the characteristics of thiamine placental transport are poorly understood, and have not been yet determined in a cell culture system, the aim of this study was to characterize the placental uptake of thiamine, by describing the properties of the apical uptake of ${ }^{3} \mathrm{H}$-thiamine by the human placental trophoblast cell line BeWo.

Moreover, this work also aimed at determining the effect of some bioactive substances present in the human diet (more specifically, in some alcoholic or non-alcoholic drinks) on the uptake of thiamine by BeWo cells. For this purpose, both the acute and chronic effect of ethanol and of some polyphenolic compounds (xantohumol, catechin, epicatechin, iso-xantohumol, resveratrol, quercetin, myricetin, epigallocatechin-3-gallate, chrysine and rutin) present in alcoholic (e.g. red wine) or nonalcoholic beverages (e.g. green tea), as well as of methylxanthines (caffeine and teophylline) present in some drinks (e.g. coffee and black tea) were also determined.

\section{Materials and Methods}

Materials. $\left[{ }^{3} \mathrm{H}(\mathrm{G})\right]$ Thiamine hydrochloride (specific activity $10-20$ $\mathrm{Ci} / \mathrm{mmol}$ ) (Biotrend Chemikalien $\mathrm{GmbH}$, Germany); caffeine (BDH Laboratory Chemicals Ltd., Poole, England); desipramine hydrochloride (Ciba-Geigy, Switzerland); amprolium hydrochloride, antibiotic/antimycotic solution (100 units $\mathrm{ml}^{-1}$ penicillin; $100 \mu \mathrm{g} \mathrm{ml} l^{-1}$ streptomycin and $0.25 \mu \mathrm{g} \mathrm{ml}^{-1}$ amphotericin B), (+)catequin hydrate, chrisine, clonidine hydrochloride, cimetidine, collagen type I, epicatechin, (-)epigallocatechin-3-gallate, fluoxetine hydrochloride, guanidine hydrochloride, Ham's F12 K (Nutrient mixture F12-Ham Kaighn's modification), HEPES (N-2-hydroxyethylpiperazine-N'2-ethanesulfonic acid), 5-hydroxytryptamine creatinine sulfate, MES (2-[N-Morpholino]ethanesulfonic acid hydrate), $N$-methylnicotinamide chloride, myricetin, oxythiamine hydrochloride, quercetin dihydrate, resveratrol, rutin, sodium azide, teophylline, tetraethylammonium hydrochloride, thiamine hydrochloride, thiamine pyrophosphate hydrochloride, trypsin-EDTA solution, xantohumol (Sigma, USA),
DMSO (dimethylsulfoxide), triton X-100, Tris (tris-(hydroxymethyl)aminomethane hydrochloride) (Merck, Germany), fetal calf serum (Invitrogen Corporation, USA).

Iso-xantohumol was kindly donated by Eng. José M. Machado Cruz, from iBeSa-Instituto de Bebidas e Saúde, S. Mamede Infesta, Portugal.

When the drugs to be tested were dissolved in ethanol or DMSO, the final concentration of these solvents was $1 \%$ in the buffer and $0.1 \%$ in the culture media (acute and chronic treatments, respectively). Controls for these drugs were run in the presence of the solvent.

BeWo cell culture. The BeWo cell line was obtained from the American Type Culture Collection (ATCC CCL-98, Rockville, MD, USA) and was used between passages 7-39. The cells were maintained in a humidified atmosphere of $5 \% \mathrm{CO}_{2}-95 \%$ air, and were grown in Ham's F12K medium containing $2.5 \mathrm{~g} / 1$ sodium bicarbonate, $10 \%$ heat-inactivated fetal calf serum and $1 \%$ antibiotic/antimycotic solution. Culture medium was changed every 2 to 3 days and the culture was split every 7 days. For subculturing, the cells were removed enzymatically $(0.25 \%$ trypsinEDTA, $5 \mathrm{~min}, 37^{\circ} \mathrm{C}$ ), split $1: 2-1: 3$, and sub-cultured in plastic culture dishes $\left(21 \mathrm{~cm}^{2} ; \phi 60 \mathrm{~mm}\right.$; TPP ${ }^{\circledR}$, Trasadingen, Switzerland). For the transport studies, BeWo cells were seeded on collagencoated 24-well plastic cell culture clusters $\left(2 \mathrm{~cm}^{2} ; \phi 16 \mathrm{~mm}\right.$; TPP $\left.{ }^{\circledR}\right)$, and were used after 3-5 days in culture (90-100\% confluence). At this moment, each square $\mathrm{cm}$ contained about $60 \mu \mathrm{g}$ cell protein.

Transport studies. The transport experiments were performed in buffer with the following composition (in $\mathrm{mM}$ ): $125 \mathrm{NaCl}, 4.8 \mathrm{KCl}$, 1.2 $\mathrm{KH}_{2} \mathrm{PO}_{4}, 12.5 \mathrm{HEPES}-\mathrm{NaOH}, 12.5 \mathrm{MES}, 1.2 \mathrm{MgSO}_{4}, 1.2 \mathrm{CaCl}_{2}$, and 5.6 $\mathrm{D}(+)$ glucose, $\mathrm{pH} 7.5$, unless otherwise stated. Initially, the culture medium was aspirated and the cells were washed twice with $0.5 \mathrm{ml}$ buffer at $37^{\circ} \mathrm{C}$; then the cell monolayers were pre-incubated for $20 \mathrm{~min}$ in $0.3 \mathrm{ml}$ buffer at $37^{\circ} \mathrm{C}$. Uptake was initiated by the addition of $0.2 \mathrm{ml}$ buffer at $37^{\circ} \mathrm{C}$ containing 50 or $100 \mathrm{nM}{ }^{3} \mathrm{H}-$ thiamine. Incubation was stopped after $3 \mathrm{~min}$ (except where indicated) by removing the incubation medium, placing the cells on ice and rinsing the cells with $0.5 \mathrm{ml}$ ice-cold buffer. The cells were then solubilized with $0.3 \mathrm{ml} 0.1 \%(\mathrm{v} / \mathrm{v})$ Triton $\mathrm{X}-100$ (in $5 \mathrm{mM}$ Tris.HCl, pH 7.4), and placed at room temperature overnight. Radioactivity in the cells was measured by liquid scintillation counting.

To study the influence of extracellular $\mathrm{Na}^{+}$and $\mathrm{Cl}^{-}$on ${ }^{3} \mathrm{H}-$ thiamine uptake, cells were pre-incubated and incubated in $\mathrm{NaCl}-$ free buffer, $\mathrm{NaCl}$ (corresponding to $125 \mathrm{mM}$ ) being isotonically replaced by either $\mathrm{LiCl}$, choline chloride or $\mathrm{NaF}$.

Acute and chronic treatment of the cells. The acute effect of compounds on ${ }^{3} \mathrm{H}$-thiamine uptake by BeWo cells was tested by pre-incubating (20 min) and incubating cells with ${ }^{3} \mathrm{H}$-thiamine (100 $\mathrm{nM} ; 3 \mathrm{~min}$ ) in the presence of these compounds.

The chronic effect of compounds on ${ }^{3} \mathrm{H}$-thiamine uptake by BeWo cells was studied by cultivating 3 days-old cell cultures in culture medium containing the compounds to be tested (ethanol, xantohumol, catechin, epicatechin, iso-xantohumol, resveratrol, quercetin, myricetin, epigallocatechin-3-gallate, chrysine, rutin, caffeine and teophylline). The medium was renewed daily, and the 
transport experiments were performed after $48 \mathrm{~h}$. The transport experiments were identical to the experiments described above, except that there was no pre-incubation period, and cells were incubated with ${ }^{3} \mathrm{H}$-thiamine $(100 \mathrm{nM})$ for $3 \mathrm{~min}$ in the absence of drugs.

The concentrations of compounds to test in both acute and chronic treatment of the cells were chosen based on previous works from our group (Lemos et al., 2004, 2005; Monteiro et al., 2005).

RNA extraction and RT-PCR. Total RNA was extracted from chronically-treated BeWo cells (see above) by the method of Chomczynski and Sacchi (1987). Before RNA extraction, the cell culture medium was aspirated, and the cells were resupended in buffer (with the composition shown above) and centrifuged at 3000 $\mathrm{g}$ for $5 \mathrm{~min}$, to completely remove culture medium. RNA was extracted with phenol-chloroform, precipitated with ethanol and dissolved in water. For cDNA synthesis, $5 \mu \mathrm{g}$ of the RNA thus prepared was incubated at $45^{\circ} \mathrm{C}$ for $1 \mathrm{~h}$ in a total volume of $20 \mu \mathrm{l}$ with 200 units of M-MuLV Reverse transcriptase, RNase H(Bioron $\mathrm{GmbH}$, Germany), $10 \mu \mathrm{M}$ random hexamers (Sigma, USA), $0.375 \mathrm{mM}$ per dNTP (Bioron $\mathrm{GmbH}) 3 \mathrm{mM} \mathrm{MgCl}_{2}, 100 \mathrm{mM} \mathrm{KCl}$, $50 \mathrm{mM}$ Tris- $\mathrm{HCl}, \mathrm{pH} 8.3\left(25^{\circ} \mathrm{C}\right), 10 \mathrm{mM}$ dithiothreitol, and 40 units RNase inhibitor (RNaseOUT ${ }^{\mathrm{TM}}$; Invitrogen Corporation, USA). Following heat-inactivation of the proteins $\left(10 \mathrm{~min}\right.$ at $\left.95^{\circ} \mathrm{C}\right)$ and addition of $5 \mu \mathrm{l}$ of $0.5 \mathrm{mg} / \mathrm{ml}$ DNase-free RNase A (Sigma) in $10 \mathrm{mM}$ Tris- $\mathrm{HCl}, \mathrm{pH} 8.0$ and $50 \%(\mathrm{v} / \mathrm{v})$ glycerol, the cDNA was incubated at $37^{\circ} \mathrm{C}$ for $30 \mathrm{~min}$, to degrade unreacted RNA. Using 4 $\mu l$ of this preparation, PCR was performed. The PCR reaction mixture $(50 \mu \mathrm{l})$ contained $0.5 \mu \mathrm{M}$ per primer, $0.2 \mathrm{mM}$ per $\mathrm{dNTP}$,
$2.3 \mathrm{mM} \mathrm{MgCl}_{2}$, and 2 units of DFS-Taq DNA Polymerase (Bioron $\mathrm{GmbH}$ ). Primer sequences, expected size of PCR products and thermocycling conditions used are indicated in Table 1.

Six microliters of each individual PCR reaction were then run on $1.6 \%$ agarose gel, and visualized with an ultraviolet transilluminator (Vilber Lourmat, France) using ethidium bromide staining, a COHU CCD camera and the appropriate filters for U.V. light.

Protein determination. The protein content of cell monolayers was determined as described by Bradford (1976), using human serum albumin as standard.

Calculations and statistics. For the analysis of the time course of ${ }^{3} \mathrm{H}$-thiamine uptake, the parameters of equation (1) were fitted to the experimental data by a non-linear regression analysis, using a computer-assisted method (Motulsky et al., 1994).

$$
A(t)=k_{\text {in }} / k_{\text {out }}\left(1-e^{-k o u t . t}\right)
$$

$A(t)$ represents the accumulation of ${ }^{3} \mathrm{H}$-thiamine at time $t, k_{\text {in }}$ and $\mathrm{k}_{\text {out }}$ the rate constants for inward and outward transport, respectively, and $\mathrm{t}$ the incubation time. $\mathrm{A}_{\max }$ is defined as the accumulation at steady-state $(\mathrm{t} \rightarrow \infty)$. $\mathrm{K}_{\text {in }}$ is given in pmol $\mathrm{mg}$ protein $^{-1} \min ^{-1}$ and $\mathrm{k}_{\text {out }}$ in $\mathrm{min}^{-1}$. In order to obtain clearance values, $\mathrm{k}_{\text {in }}$ was converted to $\mu \mathrm{lmg}$ protein ${ }^{-1} \mathrm{~min}^{-1}$.

Arithmetic means are given with SEM. Statistical significance of the difference between various groups was evaluated by one-way analysis of variance (ANOVA test) followed by the Bonferroni test. For comparison between two groups, Student's $t$-test was used. Differences were considered to be significant when $p<0.05$.

Table 1. Predicted size of PCR products, thermocycling conditions and primer sequences used in the amplification of the sequences corresponding to human serotonin transporter (hSERT), human thiamine transporter type 1 (hThTr-1), human thiamine transporter type 2 (hThTr-2) and glyceraldehyde-3-phosphate dehydrogenase (hGAPDH). Fwd-forward primer; Rev-reverse primer.

\begin{tabular}{|c|c|c|c|c|c|}
\hline $\begin{array}{l}\text { Gene } \\
\text { symbol }\end{array}$ & $\begin{array}{l}\text { Size of PCR } \\
\text { products (bp) }\end{array}$ & $\begin{array}{l}\text { No. } \\
\text { Cycles }\end{array}$ & $\begin{array}{l}\text { Temp. } \\
\left({ }^{\circ} \mathrm{C}\right)\end{array}$ & $\begin{array}{l}\text { Time } \\
(\mathrm{min})\end{array}$ & Primer sequence \\
\hline \multirow{5}{*}{ hSERT } & \multirow{5}{*}{319} & 1 & 94 & 5 & \multirow{5}{*}{$\begin{array}{l}\text { Fwd: 5'-CAT CTG GAA AGG CGT CAA G-3' } \\
\text { Rev: 5'-CGA AAC GAA GCT CGT CAT G-3' }\end{array}$} \\
\hline & & 30 & 94 & 1 & \\
\hline & & & 55 & 1,5 & \\
\hline & & & 72 & 1,5 & \\
\hline & & 1 & 72 & 10 & \\
\hline \multirow{5}{*}{ hTHTr-1 } & \multirow{5}{*}{154} & 1 & 95 & 5 & \multirow{5}{*}{$\begin{array}{l}\text { Fwd: 5'-GCT GCT GCA GTG TAT ATC ATG-33 } \\
\text { Rev: 5'-CAC CAA ATA CTA GGG CAT AG-3' }\end{array}$} \\
\hline & & 30 & 95 & 1 & \\
\hline & & & 56 & 1,5 & \\
\hline & & & 72 & 1,5 & \\
\hline & & 1 & 72 & 10 & \\
\hline \multirow{5}{*}{ hTHTr-2 } & \multirow{5}{*}{134} & 1 & 95 & 5 & \multirow{5}{*}{$\begin{array}{l}\text { Fwd: 5'-ACC TGA CCA GTG CAG AG-3' } \\
\text { Rev: 5'-GGT AAT GAT GAA ACT GAT-3' }\end{array}$} \\
\hline & & 30 & 95 & 1 & \\
\hline & & & 56 & 1,5 & \\
\hline & & & 72 & 1,5 & \\
\hline & & 1 & 72 & 10 & \\
\hline \multirow{2}{*}{ hGAPDH } & \multirow{2}{*}{682} & & & & Fwd: 5'-ACT GGC GTC TTC ACC ACC AT-3' \\
\hline & & & & & Rev: 5'-TCC ACC ACC CTG TTG CTG TA-3' \\
\hline
\end{tabular}




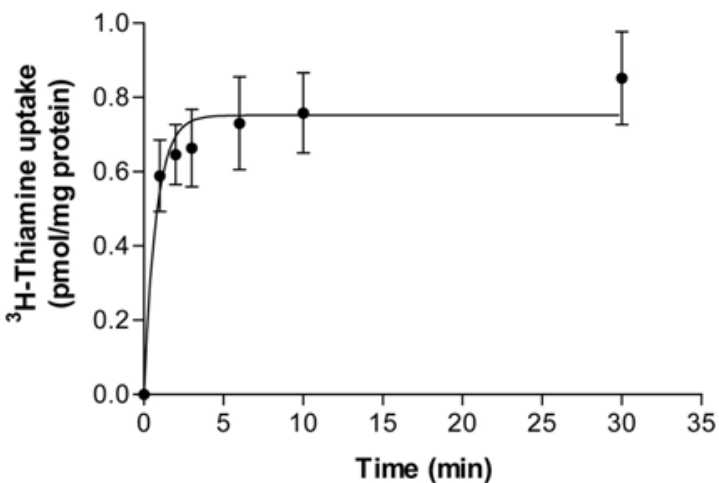

Fig. 1. Time-course of ${ }^{3} \mathrm{H}$-thiamine apical uptake by BeWo cells. Cells were incubated at $37^{\circ} \mathrm{C}$ with $50 \mathrm{nM}{ }^{3} \mathrm{H}$-thiamine. Exponential functions were fitted to the experimental data. Shown are arithmetic means $\pm \operatorname{SEM}(n=6)$.

\section{Results}

Time-course of ${ }^{3} \mathbf{H}$-thiamine uptake. In a first series of experiments, we determined the time-course of ${ }^{3} \mathrm{H}$-thiamine accumulation by BeWo cells. For this, cells were incubated with $50 \mathrm{nM}{ }^{3} \mathrm{H}$-thiamine for various periods of time. As shown in Fig. 1, BeWo cells accumulated ${ }^{3} \mathrm{H}$-thiamine in a time-dependent manner. Analysis of the time-course of ${ }^{3} \mathrm{H}$ thiamine accumulation revealed $\mathrm{a}_{\mathrm{in}}$ of $19.4 \pm 4.3 \mu \mathrm{l} \mathrm{mg}$ protein $^{-1} \mathrm{~min}^{-1}$, a $\mathrm{k}_{\text {out }}$ of $1.29 \pm 0.31 \mathrm{~min}^{-1}$ and an $\mathrm{A}_{\max }$ of $0.75 \pm 0.03$ pmol mg protein $^{-1}(n=36)$.

Analysis of the time-course of ${ }^{3} \mathrm{H}$-thiamine uptake showed that uptake was linear with time for up to $3 \mathrm{~min}$ of incubation, after which uptake reached a plateau (Fig. 1). On the basis of this information, a 3-min incubation time was selected as the standard incubation time in subsequent experiments.

pH-dependence of ${ }^{3} \mathbf{H}$-thiamine uptake. The effect of extracellular medium $\mathrm{pH}$ on ${ }^{3} \mathrm{H}$-thiamine uptake was examined by varying the $\mathrm{pH}$ of the pre-incubation and incubation media over the range between 5 and 8.5. As shown in Fig. 2, there was a marked increase in ${ }^{3} \mathrm{H}$-thiamine $(50 \mathrm{nM})$ uptake when the $\mathrm{pH}$ was decreased from physiological $(\mathrm{pH} 7.5)$ to acidic (pH 5-6).

Ion-dependence of ${ }^{\mathbf{3}} \mathbf{H}$-thiamine uptake. In another series of experiments, we examined $\mathrm{Na}^{+}$and $\mathrm{Cl}^{-}$-dependence of ${ }^{3} \mathrm{H}$ thiamine $(50 \mathrm{nM})$ uptake by isotonically replacing $\mathrm{NaCl}$ in the pre-incubation and incubation media with either $\mathrm{LiCl}$, choline chloride or NaF. As shown in Fig. 3, uptake of ${ }^{3} \mathrm{H}$-thiamine was significantly reduced when $\mathrm{NaCl}$ was substituted by either $\mathrm{LiCl}$ or choline chloride (i.e. it is $\mathrm{Na}^{+}$-dependent). On the other hand, substitution of $\mathrm{NaCl}$ by $\mathrm{NaF}$ had no effect on the uptake of this vitamin (i.e. it is $\mathrm{Cl}^{-}$-independent).

Temperature- and energy-dependence of ${ }^{3} \mathbf{H}$-thiamine uptake. Temperature-dependency of ${ }^{3} \mathrm{H}$-thiamine $(100 \mathrm{nM})$ uptake by BeWo cells was investigated by pre-incubating and incubating

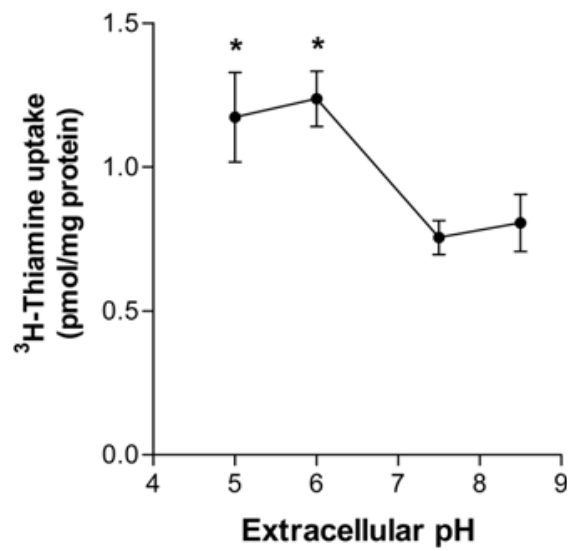

Fig. 2. pH-dependence of ${ }^{3} \mathrm{H}$-thiamine apical uptake by BeWo cells. Cells were incubated at $37^{\circ} \mathrm{C}$ with $50 \mathrm{nM}{ }^{3} \mathrm{H}$-thiamine for $3 \mathrm{~min}$. The extracellular $\mathrm{pH}$ in the pre-incubation and incubation media ranged from 5.0 to 8.5. Shown are arithmetic means \pm SEM $(n=8)$. *Significantly different from uptake at $\mathrm{pH} 7.5$ $(p<0.05)$

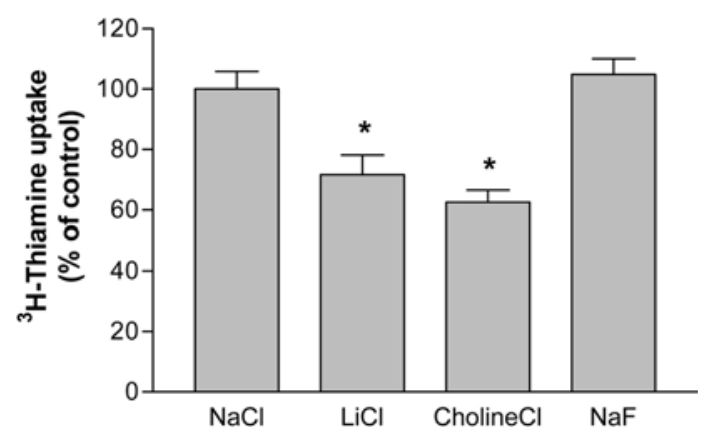

Fig. 3. Ionic-dependence of ${ }^{3} \mathrm{H}$-thiamine apical uptake by BeWo cells. Cells were incubated at $37^{\circ} \mathrm{C}$ with $50 \mathrm{nM}{ }^{3} \mathrm{H}$-thiamine for $3 \mathrm{~min} . \mathrm{NaCl}$ in the extracellular medium was isotonically replaced by either $\mathrm{LiCl}$, cholineCl or $\mathrm{NaF}$. Shown are arithmetic means \pm SEM. $(n=5)$. *Significantly different from control $(p<0.05)$

the cells at $4^{\circ} \mathrm{C}$. This condition caused a small, but significant, reduction in ${ }^{3} \mathrm{H}$-thiamine uptake. On the other hand, sodium azide $(10 \mathrm{mM})$, a metabolic inhibitor, produced no effect on the uptake of ${ }^{3} \mathrm{H}$-thiamine (Fig. 4).

Specificity of ${ }^{3} \mathbf{H}$-thiamine uptake. In a first series of experiments, the specificity of ${ }^{3} \mathrm{H}$-thiamine uptake by BeWo cells was investigated by testing the effect of thiamine and thiamine analogs. As shown in Fig. 5, thiamine $(100 \mu \mathrm{M})$ produced a decrease in ${ }^{3} \mathrm{H}$-thiamine $(100 \mathrm{nM})$ uptake, but none of its structural analogs had any significant effect.

We next examined the effect of several unrelated organic cations on the uptake of ${ }^{3} \mathrm{H}$-thiamine $(100 \mathrm{nM})$. Interestingly, all the compounds tested (guanidine, $N$-methylnicotinamide, tetraethylammonium, clonidine and cimetidine) caused a reduction in ${ }^{3} \mathrm{H}$-thiamine uptake. The percent inhibition observed with all these compounds was similar (20-30\%) (Fig. 6). 


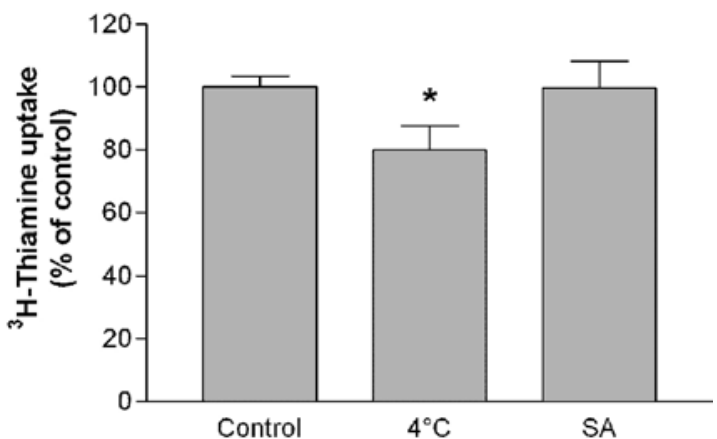

Fig. 4. Temperature- and energy-dependence of ${ }^{3} \mathrm{H}$-thiamine apical uptake by BeWo cells. Cells were incubated with $100 \mathrm{nM}{ }^{3} \mathrm{H}-$ thiamine for $3 \mathrm{~min}$ at $37^{\circ} \mathrm{C}$ (control), $4^{\circ} \mathrm{C}$, or at $37^{\circ} \mathrm{C}$ but in the presence of sodium azide (SA; $10 \mathrm{mM})$. Shown are arithmetic means \pm SEM $(n=5-8)$. *Significantly different from control $(p<0.05)$.

We also tested the effect of serotonin (5-hydroxytryptamine), another organic cation, on ${ }^{3} \mathrm{H}$-thiamine uptake. This compound $(100-1000 \mu \mathrm{M})$ reduced ${ }^{3} \mathrm{H}$-thiamine uptake: at $100 \mu \mathrm{M}$, it caused a $50 \%$ reduction of ${ }^{3} \mathrm{H}$-thiamine uptake. Interestingly, fluoxetine $(1 \mu \mathrm{M})$ and desipramine $(10 \mu \mathrm{M})$, two known inhibitors of the plasmalemmal serotonin transporter hSERT, caused also an inhibition of ${ }^{3} \mathrm{H}$-thiamine uptake by BeWo cells (Fig. 7).
The relation between serotonin and thiamine was further examined by testing the efficiency of serotonin to accelerate the countertransport of ${ }^{3} \mathrm{H}$-thiamine. Cells were pre-incubated for $20 \mathrm{~min}$ with unlabeled serotonin $(300 \mu \mathrm{M})$. After thorough washing (three times with $0.3 \mathrm{ml}$ ice-cold buffer) to remove serotonin from extracellular space, uptake of ${ }^{3} \mathrm{H}$-thiamine (3 min; $100 \mathrm{nM}$ ) was measured in the absence of the drug. Controls were pre-incubated in the absence of drug. The results obtained showed a tendency for a reduction of ${ }^{3} \mathrm{H}$ thiamine uptake by serotonin (trans-inhibition), although the decrease observed (to $77.7 \pm 9.7 \%$ of control; $n=7$ ) did not reach statistical significance.

Effect of dietary bioactive compounds on ${ }^{3} \mathrm{H}$-thiamine uptake Acute effect. The acute effect of different concentrations of ethanol $(0.5,1$ and $5 \%(\mathrm{v} / \mathrm{v}))$ on ${ }^{3} \mathrm{H}$-thiamine uptake by BeWo cells was tested. We verified that none of these concentrations of ethanol had any significant effect upon this parameter (uptake of the vitamin in the presence of $0.5,1$ and $5 \%(\mathrm{v} / \mathrm{v})$ ethanol corresponded to $92.8 \pm 7.2,96.4 \pm 3.9$ and $99.1 \pm 9.3 \%$ of control, respectively $(n=5-6))$.

The acute effect of some polyphenolic compounds (xantohumol, catechin, epicatechin, iso-xantohumol, resveratrol, quercetin, myricetin, epigallocatechin-3-gallate, chrysine and rutin), as well as of two methylxanthines (caffeine and teophylline) was

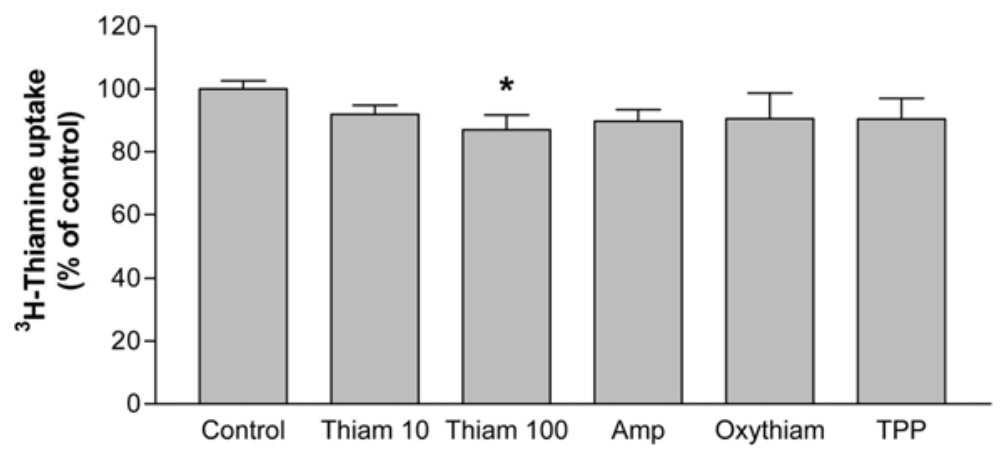

Fig. 5. Effect of thiamine $10-100 \mu \mathrm{M}$ (Thiam; $n=5-6$ ), amprolium $100 \mu \mathrm{M}$ (Amp; $n=7$ ); oxythiamine $100 \mu \mathrm{M}(\mathrm{Oxy}$ thiam; $n=7)$ and thiamine pyrophosphate $100 \mu \mathrm{M}$ (TPP; $n=7$ ) on ${ }^{3} \mathrm{H}$-thiamine apical uptake by BeWo cells. Cells were incubated at $37^{\circ} \mathrm{C}$ with $100 \mathrm{nM}$ ${ }^{3} \mathrm{H}$-thiamine for $3 \mathrm{~min}$. Shown are arithmetic means \pm SEM. *Significantly different from control $(p<0.05)$.

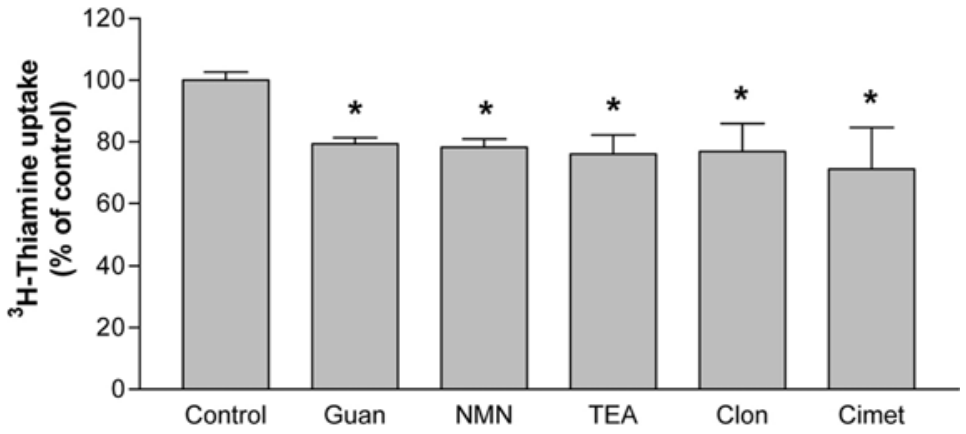

Fig. 6. Effect of guanidine (Guan; $n=5), N$-methylnicotinamide (NMN; $n=6$ ), tetraethylammonium (TEA; $n=7)$, clonidine (Clon; $n=5$ ) and cimetidine (Cim; $n=5)$, all at $100 \mu \mathrm{M}$, on ${ }^{3} \mathrm{H}$-thiamine apical uptake by BeWo cells. Cells were incubated at $37^{\circ} \mathrm{C}$ with $100 \mathrm{nM}$ ${ }^{3} \mathrm{H}$-thiamine for $3 \mathrm{~min}$. Shown are arithmetic means \pm SEM. * Significantly different from control $(p<0.05)$ 


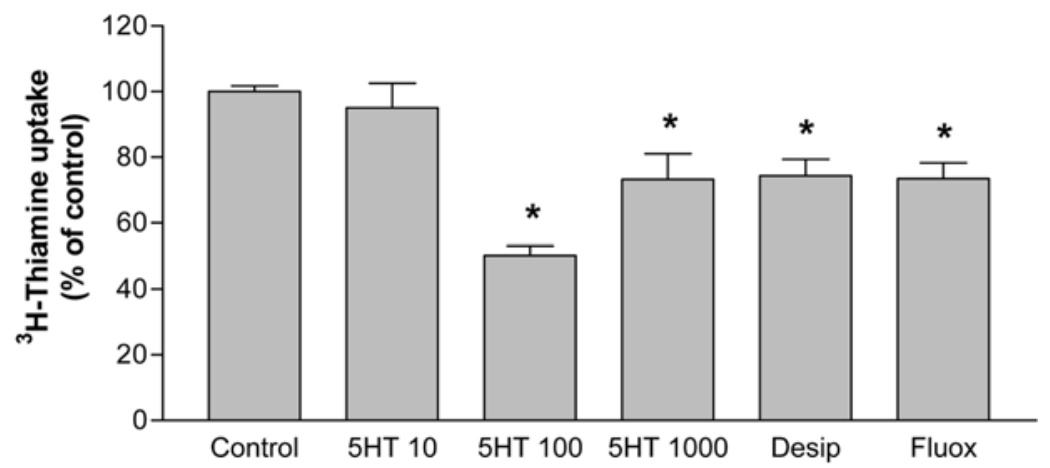

Fig. 7. Effect of serotonin (5-hydroxytryptamine) $10-1000 \mu \mathrm{M}$ (5HT; $n=4-7)$, desipramine $10 \mu \mathrm{M}$ (Desip; $n=6)$ and fluoxetine $1 \mu \mathrm{M}$ (Fluox; $n=6$ ) on ${ }^{3} \mathrm{H}$-thiamine apical uptake by BeWo cells. Cells were incubated at $37^{\circ} \mathrm{C}$ with $100 \mathrm{nM}{ }^{3} \mathrm{H}$-thiamine for 3 min. Shown are arithmetic means \pm SEM. *Significantly different from control $(p<0.05)$.

also determined. None of these compounds (all tested at 10 $\mu \mathrm{M} ; n=4-6)$ had a significant effect upon ${ }^{3} \mathrm{H}$-thiamine uptake (results not shown).

Chronic effect. The chronic (48 h) effect of different concentrations of ethanol $(0.01,0.05$ and $0.1 \%(\mathrm{v} / \mathrm{v}))$ on ${ }^{3} \mathrm{H}-$ thiamine uptake by BeWo cells was also tested. Similarly to what was verified with acute exposure to this agent, none of these concentrations of ethanol had any significant effect upon uptake of the vitamin when tested chronically (uptake in the presence of $0.01,0.05$ and $0.1 \%(\mathrm{v} / \mathrm{v})$ ethanol corresponded to $106.3 \pm 3.1,109.64 \pm 5.1$ and $101.9 \pm 3.7 \%$ of control, respectively $(\mathrm{n}=5-10))$.

The chronic effect of the polyphenolic compounds and methylxanthines tested acutely (see above) was also determined. Of all the compounds tested (both at 0.1 and $1 \mu \mathrm{M}$ ), significant effects were found for three compounds: caffeine, xantohumol and iso-xantohumol. Caffeine $(1 \mu \mathrm{M})$ caused an increase in ${ }^{3} \mathrm{H}$-thiamine uptake (to $122.7 \pm 14.0 \%$ of control; $n=6$ ), and both xantohumol $(1 \mu \mathrm{M})$ and iso-xantohumol $(0.1 \mu \mathrm{M})$ caused a significant reduction of ${ }^{3} \mathrm{H}$-thiamine uptake (to $91.1 \pm 2.7 \%$ and $88.0 \pm 3.7 \%$ of control, respectively; $n=5-6$ ).

Effect of dietary bioactive compounds on hThTr-1, hThTr-2 and hSERT expression. In order to study the ethiology of the observed chronic effects of dietary compounds, we first examined the pattern of expression of hThTr-1, hThTr-2 and hSERT in BeWo cells under standard culture conditions. By using RT-PCR, this cell line was found to express hThTr-1, very low levels of hThTr-2, and, as already described elsewhere, hSERT (Figs. 8a, b). Levels of hThTr-1 expression were found to be significantly higher than levels of hSERT expression in this cell line (Fig. 8c).

Then, we performed RT-PCR using BeWo cells chronically treated with the compounds that had a significant effect upon the uptake of ${ }^{3} \mathrm{H}$-thiamine. Because the levels of expression of hThTr-2 were extremely low, we did not study the effect of chronic treatment of BeWo cells upon this transporter. As can be observed in Fig. 9, neither the expression of hSERT nor the expression of hThTr-1 were affected by chronic exposure of BeWo cells to caffeine $(1 \mu \mathrm{M})$, xantohumol $(1 \mu \mathrm{M})$ or isoxantohumol $(0.1 \mu \mathrm{M})$.

\section{Discussion}

The aim of this work was to characterize the uptake of thiamine at the apical membrane of the human syncytiotrophoblast, and to determine both the acute and the chronic effect of some dietary bioactive compounds on this mechanism. For this purpose, we studied ${ }^{3} \mathrm{H}$-thiamine uptake by BeWo cells. The BeWo cell line derives from a human gestational choriocarcinoma, and is a known cellular model of the human syncytiotrophoblast (Liu et al., 1997; Rama Sastry, 1999), having been much used as cell model to investigate placental trophoblast transport function for a number of compounds. BeWo cells, besides exhibiting morphological properties, producing biochemical marker enzymes and secreting hormones characteristic of normal trophoblasts, rapidly form a confluent polarized monolayer, being particularly attractive for studies on transplacental barrier (Liu et al., 1997). Indeed, they have been shown to exhibit polarized nutrient uptake systems (Moe et al., 1994; Eaton and Sooranna, 1996), and polarized transcellular transport of transferrin (Cerneus and van der Ende, 1991) and serotonin (Prasad et al., 1996).

The results obtained in this study concerning the characterization of ${ }^{3} \mathrm{H}$-thiamine uptake may be summarized as follow. ${ }^{3} \mathrm{H}$-thiamine uptake by BeWo cells was: 1) temperaturedependent and energy-independent; 2) $\mathrm{pH}$-dependent (with uptake increasing with decreasing extracellular medium $\mathrm{pH}$ ); 3) $\mathrm{Na}^{+}$-dependent and $\mathrm{Cl}^{-}$-independent; 4) not inhibited by thiamine structural analogs (amprolium, oxythiamine and thiamine pyrophosphate); 5) inhibited by several structurally unrelated organic cations (guanidine, $N$-methylnicotinamide, tetraethylammonium, clonidine and cimetidine); 6) inhibited by the organic cation serotonin, and by two selective inhibitors of the serotonin plasmalemmal transporter (hSERT), fluoxetine and desipramine. 
(A)

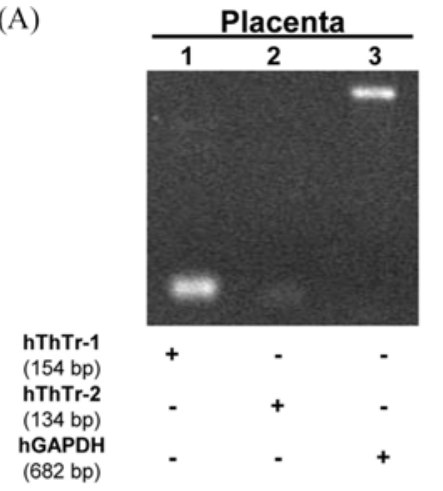

(B)

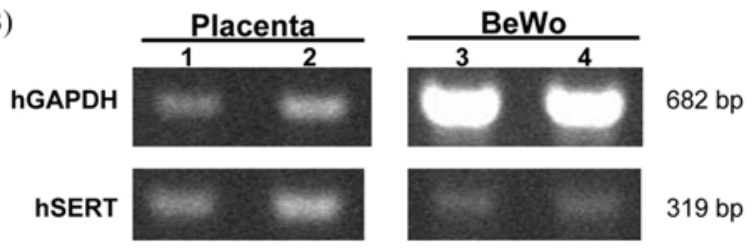

(C)

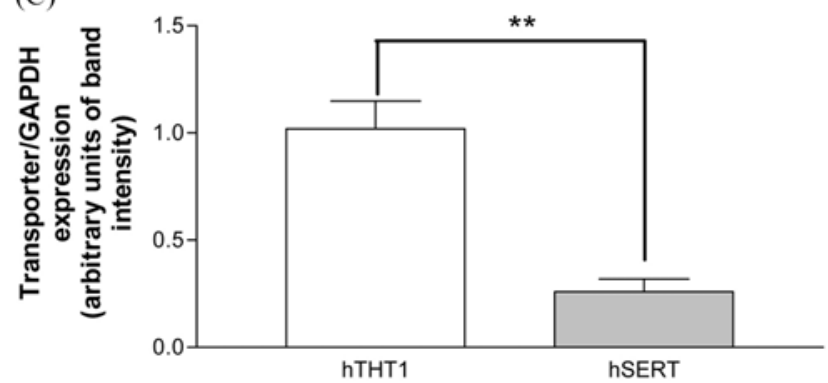

Fig. 8. Detection by RT-PCR of hThTr-1, hThTr- 2 and hSERT mRNA in total RNA from BeWo cells and human placenta. a) RT-PCR analysis with specific primers for hThTr-1 (lanes 1 and 4) and hThTr-2 (lanes 2 and 5). b) RT-PCR analysis with specific primers for hSERT (lanes 1-4). Human placental tissue was used as a positive control. As control for the intactness of mRNA, hGAPDH mRNA was detected with specific primers. PCR products were separated by agarose gel electrophoresis, followed by ethidium bromide staining. c) Quantitative analysis of hThTr-1 and hSERT mRNA expression. Relative band densities, hThTr-1/hGAPDH or hSERT/hGAPDH, were calculated. Shown are arithmetic means \pm SEM. **Significantly different $(p<0.01)$.

Analysis of these results suggests that ${ }^{3} \mathrm{H}$-thiamine uptake by BeWo cells involves a transporter distinct from the previously described thiamine transporter(s). Indeed, the characteristics of ${ }^{3} \mathrm{H}$-thiamine uptake by BeWo cells are distinct from the characteristics of thiamine uptake in several other cell types (e.g. human enterocytes (Caco-2 cells), human colonocytes (NCM460 cells) and human hepatocytes (HepG2 cells)) (Said et al., 1999, 2001, 2002). Moreover, they are also distinct from the characteristics of two recently cloned plasmalemmal thiamine transporters, hThTr-1 and hThTr-2, belonging to the SLC19A family (Diaz et al., 1999; Dutta et al., 1999; Fleming

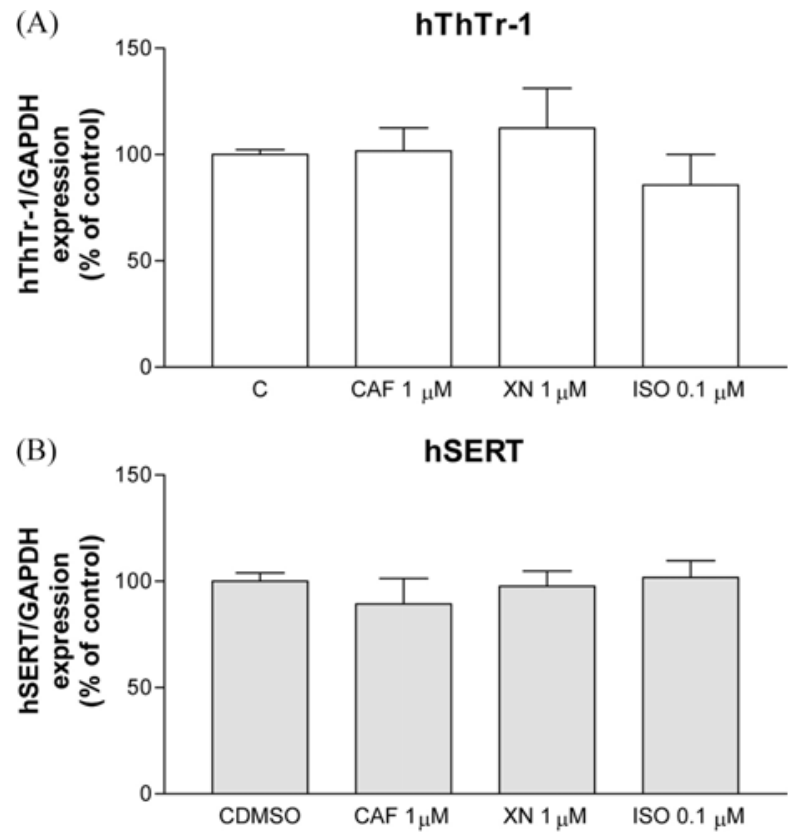

Fig. 9. Analysis of mRNA levels for a) hThTr-1 and b) hSERT in BeWo cells chronically exposed to caffeine (CAF), xantohumol (XN) and isoxantohumol (ISO). BeWo cells were treated with the indicated concentrations of the different compounds or with the respective solvent (control, C) for $48 \mathrm{~h}$ at $37^{\circ} \mathrm{C}$. Total RNA was then isolated from these cells and used for semi-quantitative RT-PCR. Specific primers for hThTr-1 and hSERT were used. As control for the intactness of mRNA, hGAPDH mRNA was detected with specific primers. PCR products were separated by agarose gel electrophoresis, followed by ethidium bromide staining. Relative band densities (hThTr-1/hGAPDH or hSERT/ hGAPDH) were calculated and the hThTr-1-to-hGAPDH or hSERT-to-hGAPDH ratios in control cells were taken as $100 \%$. Shown are arithmetic means \pm SEM of three determinations from two independent experiments. *Significantly different from control $(p<0.05)$.

et al., 1999; Labav et al., 1999; Eudy et al., 2000). Finally, they are also distinct from the characteristics of thiamine uptake by human placental brush border membrane vesicles (Grassl, 1998). Interestingly, thiamine uptake by all these cell types/models/transporters shows similar characteristics, which are, however, very distinct from the characteristics of ${ }^{3} \mathrm{H}$ thiamine uptake by BeWo cells: $\mathrm{Na}^{+}$-independence, $\mathrm{pH}$ dependence (but with uptake decreasing as the $\mathrm{pH}$ decreases from physiological to acidic), inhibition by thiamine analogs (e.g. amprolium and oxythiamine) and lack of inhibition by unrelated organic cations (e.g. guanidine and cimetidine).

As stated above, our results suggest that ${ }^{3} \mathrm{H}$-thiamine is not transported by hThTr-1 or hThTr-2, in BeWo cells. One possible explanation for this observation is that BeWo cells do not express these transporters. However, as our results demonstrate for the first time, BeWo cells do express hThTr-1 and hThTr-2 mRNA. This result is not unexpected, as both hThTr-1 and hThTr-2 are widely expressed in human tissues, 
being actually very abundant in the placenta (hThTr-1 is most abundant in skeletal muscle, followed by heart, placenta, kidney and liver (Diaz et al., 1999; Dutta et al., 1999; Fleming et al., 1999; Labav et al., 1999, and hThTr-2 is most abundant in placenta, followed by liver, kidney and heart (Eudy et al., 2000)).

Analysis of the results obtained in this study shows that ${ }^{3} \mathrm{H}-$ thiamine uptake by BeWo cells presents, on the other hand, many similarities with hSERT-mediated transport. hSERT, a highly selective serotonin plasmalemmal transporter (Ramamoorthy et al., 1993), is a sodium- and chloridedependent carrier belonging to a gene family of monoamine transporters (which also includes norepinephrine (NAT) and dopamine (DAT) transporters). hSERT is effectively inhibited by amphetamines, cocaine, tricyclic antidepressants (e.g. desipramine) and, most selectively, by serotonin-selective reuptake inhibitors (SSRIs) such as fluoxetine (Blakely et al., 1994; Gainetdinov and Caron, 2003). This transporter is responsible for the physiological inactivation of serotonin, by removing serotonin from the extracellular space. hSERT is primarily present in serotoninergic neurons both at the CNS and periphery, but it is also found in other cell types such as enterocytes (Wade et al., 1996; Chen et al., 1998). Moreover, hSERT is also present in the human placenta (Nguyen et al., 1999; Ganapathy et al., 1999), and is also constitutively expressed in human placental choriocarcinoma JAR and BeWo cell lines (Cool et al., 1991; Jayanthi et al., 1994; Prasad et al., 1996). Interestingly, these cell lines are the only cell lines of human origin that constitutively express hSERT. In this paper, we confirm the presence of hSERT mRNA both in the human placenta and BeWo cells.

Characteristics of ${ }^{3} \mathrm{H}$-thiamine uptake by BeWo cells suggestive of hSERT involvement are its $\mathrm{Na}^{+}$-dependence, its inhibition by serotonin and its inhibition by two selective hSERT inhibitors: desipramine and fluoxetine. Interestingly enough, our group recently verified that some of the organic cations that decreased ${ }^{3} \mathrm{H}$-thiamine uptake in BeWo cells (clonidine, cimetidine and tetraethylammonium) also inhibited hSERT-mediated serotonin transport in human placental JAR cells (Keating et al., 2004). In the same study, it was also found that a high concentration of thiamine $(3 \mathrm{mM})$ was able to decrease hSERT-mediated serotonin uptake, thus raising the hypothesis that thiamine is also a substrate of hSERT (Keating et al., 2004).

In our experiments, serotonin was devoid of trans-stimulation effect on ${ }^{3} \mathrm{H}$-thiamine uptake by BeWo cells. Although this result seems to argue against the hypothesis of thiamine and serotonin being substrates of the same transporter in BeWo cells, because the ability of a compound to trans-stimulate a carrier-mediated mechanism clearly demonstrates that the compound is a substrate for that carrier, lack of transstimulation (or even trans-inhibition) by a given compound does not necessarily imply that this compound is not a substrate of the carrier. Indeed, several reasons may explain lack of trans-stimulation by substrates, including: (1) a tight bind to the transporter, while being transported, with poor dissociation from it during the experimental procedures, (2) binding or sequestration by intracellular compartments, after being transported, or (3) rapid metabolism to derivatives that do not exit cells, after being transported. So, from our transeffect results, we cannot exclude the possibility of thiamine and serotonin being substrates of the same transporter in BeWo cells.

To our knowledge, this is the first report suggesting that thiamine might be transported by hSERT. As to the affinity of hSERT in relation to thiamine, our results suggest that it is low, because $100 \mu \mathrm{M}$ thiamine had only a small inhibitory effect upon ${ }^{3} \mathrm{H}$-thiamine uptake by BeWo cells. Interestingly, this low affinity is in agreement with the recently described modest inhibition of hSERT-mediated uptake of ${ }^{3} \mathrm{H}$-serotonin by a high concentration ( $3 \mathrm{mM}$ ) of thiamine (Keating et al., 2004). The affinity of hSERT in relation to thiamine might be, however, somehow underestimated in the present study, because, most probably, there is a hSERT-independent component of ${ }^{3} \mathrm{H}$-thiamine uptake in BeWo cells. This component, which might represent as much as $50 \%$ of ${ }^{3} \mathrm{H}-$ thiamine uptake (because neither $\mathrm{Na}^{+}$-removal, nor serotonin nor SSRIs were able to reduce ${ }^{3} \mathrm{H}$-thiamine more than 50 $60 \%$ ), might correspond to non-specific transport of thiamine.

As to the physiological consequences of this interaction between thiamine and hSERT, it might be speculated that high maternal blood concentrations of serotonin as those seen in pre-eclamptic pregnancies (Gujrati et al., 1996; Carrasco et al., 1998, 2000) might inhibit the placental uptake of thiamine, thus decreasing the fetal availability of thiamine. On the other hand, high maternal blood levels of thiamine, resulting e.g. from maternal supplementation with this vitamin, might inhibit hSERT-mediated placental uptake of serotonin. Removal of serotonin by placental hSERT may be involved in the clearance of maternal serotonin, a potent placental vasoconstrictor, from the intervillous space. Such a process may be essential to maintain the uteroplacental blood flow (Ganapathy and Leibach, 1994; Ganapathy et al., 1999).

In this work, we also aimed at determining both the acute and chronic effect of some bioactive substances present in alcoholic and non-alcoholic drinks on ${ }^{3} \mathrm{H}$-thiamine placental uptake. We focused our attention on ethanol, because it is the most frequently used drug worldwide (chronic alcohol addiction affects at least $5 \%$ of the U.S. population (Halsted et $a l ., 2002)$ ), and because, among the wide variety of medical problems caused by alcohol abuse, chronic alcoholism is known for a long time to cause deficiency of several nutrients, including thiamine (Tanphaichitr, 1999; Thomson, 2000; van den berg et al., 2002), which might contribute to fetal alcohol syndrome (Levin et al., 1985). However, the effect of alcoholism is usually inferred from in vitro or in vivo experiments where the effect of ethanol alone is examined, and alcoholic beverages contain many other biologically active compounds, many of which possess beneficial effects for human health. In particular, red wine contains many 
phenolic compounds with antioxidant properties, and the beneficial effect of these compounds on heart disease, cancer and inflammatory diseases is becoming increasingly evident (German and Walzem, 2000; Middleton et al., 2000; Sun et al., 2002). For this reason, in addition to ethanol, we also determined the effect of some other bioactive compounds present in large-scale consumed drinks: polyphenolic compounds present in alcoholic (e.g. red wine) and nonalcoholic beverages (e.g. green tea), and methylxanthines present in some drinks (coffee and black tea).

From our results, we conclude that acute exposition of BeWo cells to ethanol, to the polyphenolic compounds xantohumol, catechin, epicatechin, iso-xantohumol, resveratrol, quercetin, myricetin, epigallocatechin-3-gallate, chrysine and rutin and to the methylxanthines caffeine and theophylline had no effect on the uptake of ${ }^{3} \mathrm{H}$-thiamine. Moreover, most of these compounds were also found to be devoid of effect on ${ }^{3} \mathrm{H}$-thiamine uptake when tested chronically. However, caffeine caused a $20 \%$ increase in ${ }^{3} \mathrm{H}$-thiamine uptake, and xantohumol and iso-xantohumol caused a small (10\%) decrease in this parameter.

Although chronic alcoholism is known for a long time to cause deficiency of thiamine (see above), the mechanism underlying this effect is still not precisely known. Indeed, it is believed that in chronic alcoholics, all possible causes of thiamine deficiency (inadequate ingestion, inadequate intestinal absorption, inadequate utilization, increased requirement, increased excretion, and increased destruction) may occur simultaneously. Our results showing that both acute and chronic ethanol were devoid of effect upon ${ }^{3} \mathrm{H}$-thiamine uptake by BeWo cells suggest that the effects of ethanol on thiamine fetal status are not due to inhibition of thiamine placental uptake. So, fetal thiamine deficiency occurring in fetal alcohol syndrome most probably results more from an inadequate supply of thiamine from the mother, rather than from a decrease in thiamine placental transfer. Interestingly, a lack of effect of ethanol upon the placental uptake of this vitamin was observed in a previous report using perfused human placenta (Schenker et al., 1990), and ethanol was also found to have no effect on thiamine intestinal absorption (Hoyumpa et al., 1975, 1978; Breen et al., 1985).

In relation to the caffeine effect, medical literature contains many varied references that appear to indicate that human adverse reproductive/developmental effects (occurrence of congenital malformations, fetal growth retardation, small-fordate babies, miscarriages (spontaneous abortions), behavioral effects, and maternal fertility) are produced by this widespread natural methylxanthine. However, the current opinion is that caffeine is a chemical that may have the potential to injure the embryo if used in marked excess, but the usual range of human exposures to caffeine from food and beverages is below the threshold dose that would result in developmental/ teratogenic or reproductive effects (Nehlig and Debry, 1994; Christian and Brent, 2001). Our results showing that caffeine increased placental uptake of thiamine suggest that, at the concentrations used in this study, this compound has no adverse effect in relation to fetal thiamine status. As to the effect of xantohumol and iso-xantohumol, pharmacological studies have shown that the former compound possesses beneficial effects to the human health, because of its marked antioxidant and antiproliferative effects (Stevens and Page, 2004). Xanthohumol is the major prenylated flavonoid in hop plants and as such a constituent of beer. Interestingly, isoxanthohumol, which similarly to xantohumol was also shown to reduce uptake of ${ }^{3} \mathrm{H}$-thiamine by BeWo cells, is a metabolite of xanthohumol formed by isomerization of xanthohumol during the brewing process and in the stomach (Stevens and Page, 2004).

By using RT-PCR, we verified that the chronic effects of caffeine, xantohumol and iso-xantohumol are not related to changes in the expression levels of hThTr-1 or hSERT mRNA. The lack of effect of the chronic treatments in the gene expression of hThTr-1 is in agreement with our results of functional characterization, which suggest that neither hThTr1 nor hThTr-2 are involved in ${ }^{3} \mathrm{H}$-thiamine uptake by BeWo cells.

The lack of effect of chronic treatment with these compounds in the expression level of hSERT indicates that another mechanism must be responsible for their inhibitory effect upon ${ }^{3} \mathrm{H}$-thiamine uptake. Among the mechanisms that could be involved, it is possible that these compounds inhibit the function of this transporter (thus affecting its kinetic parameters). It is also possible that these chronic treatments otherwise affect expression or activity of enzymes crucial for thiamine utilization and metabolism. One of these enzymes is thiamine diphosphokinase that diphosphorylates thiamine immediately after entering the cell, to give the active cofactor thiamine diphosphate (Singleton and Martin, 2001). The combined activities of thiamine uptake and thiamine diphosphokinase results in thiamine uptake. So, a reduction in thiamine diphosphokinase activity can cause reduced thiamine uptake.

In summary, this paper describes the characteristics of ${ }^{3} \mathrm{H}$ thiamine uptake by BeWo cells, and suggests that this process involves neither hThTr-1 nor hThTr-2, but rather involves the serotonin plasmalemmal transporter hSERT. It also shows that chronically, caffeine, xanthohumol and iso-xanthohumol had significant effects upon ${ }^{3} \mathrm{H}$-thiamine uptake by these cells which are, however, not mediated by variation of gene expression of hThTr-1 or hSERT.

Acknowledgments This work was supported by FCT and Programa Ciência, Tecnologia e Inovação do Quadro Comunitário de Apoio (POCTI/SAU-FCF/59382/2004).

\section{References}

Blakely, R. D., De Felice, L. J. and Hartzell, H. C. (1994) Molecular physiology of norepinephrine and serotonin 
transporters. J. Exp. Biol. 196, 263-281.

Bradford, M. M. (1976) A rapid method for the quantitation of microgram quantities of protein utilizing the principle of protein-dye binding. Anal. Biochem. 72, 248-254.

Breen, K. J., Buttigieg, R., Iossifidis, S., Lourensz and C., Wood, B. (1985) Jejunal uptake of thiamin hydrochloride in man: influence of alcoholism and alcohol. Am. J. Clin. Nutr. 42, 121-126.

Carrasco, G., Cruz, M. A., Gallardo, V., Miguel, P., Lagos, M. and Gonzalez, C. (1998) Plasma and platelet concentration and platelet uptake of serotonin in normal and pre-eclamptic pregnancies. Life Sci. 62, 1323-1332.

Carrasco, G., Cruz, M. A., Dominguez, A., Gallardo, V., Miguel, P. and Gonzalez, C. (2000) The expression and activity of monoamine oxidase $\mathrm{A}$, but not of the seroronin transporter, is decreased in human placenta from pre-eclamptic pregnancies. Life Sci. 67, 2961-2969.

Cerneus, D. P. and van der Ende, A. (1991) Apical and basolateral transferrin receptors in polarized BeWo cells recycle through separate endosomes. J. Cell. Biol. 114, 1149-1158.

Chen, J. -X., Pan, H., Rothman, T. P., Wade, P. R. and Gershon, M. D. (1998) Guinea-pig 5-HT transporter: cloning, expression, distribution, and function in intestinal sensory reception. Am. J. Physiol. 275, G433-G448.

Chomczynski, P. and Sacchi, N. (1987) Single-step method of RNA isolation by acid guanidinium thiocyanate-phenolchloroform extraction. Anal. Biochem. 162, 156-159.

Christian, M. S. and Brent, R. L. (2001) Teratogen update: evaluation of the reproductive and developmental risks of caffeine. Teratology 64, 51-78.

Cool, D. R., Leibach, F. H., Bhalla, V. K., Mahesh, V. B. and Ganapathy, V. (1991) Expression and cyclic AMP-dependent regulation of a high affinity serotonin transporter in the human placental choriocarcinoma cell line (JAR). J. Biol. Chem. 266, 15750-15757.

Dancis, J., Wilson, D., Hoskins, I. A. and Levitz, M. (1988) Placental transfer of thiamine in the human subject: in vitro perfusion studies and maternal-cord plasma concentrations. $\mathrm{Am}$. J. Obstr. Gynecol. 59, 1435-1439.

Diaz, G. A., Banikazemi, M., Oishi, K., Desnick, R. J. and Gelb, B. D. (1999) Mutations in a new gene encoding a thiamine transporter cause thiamine responsive megaloblastic anaemia syndrome. Nat. Genet. 22, 309-312.

Dutta, B., Huang, W. and Molero, M. (1999) Cloning of the human thiamine transporter, a member of the folate transporter family. J. Biol. Chem. 274, 31925-31929.

Eaton, B. M. and Sooranna, S. R. (1996) Superfused microcarrier cultures of choriocarcinoma cells: a dynamic model for studying transport of glucose and amino acids. Placenta 17, 209-215.

Eudy, J. D., Spiegelstein, O., Barber, R. C., Wlodarczyk, B. J., Talbot, J. and Finnell, R. H. (2000) Identification and characterization of human and mouse SLC19A3 gene: a novel member of the reduced folate family of micronutrient transporter genes. Mol. Genet. Metab. 71, 581-590.

Fleming, J. C., Tartaglini, E., Steinkamp, M. P., Schorderet, D. F., Cohen, N. and Neufeld, E. J. (1999) The gene mutated in thiamine-responsive anaemia with diabetes and deafness (TRMA) encodes a functional thiamine transporter. Nat. Genet. 22, 305-308.
Gainetdinov, R. R. and Caron, M. G. (2003) Monoamine transporters: from genes to behaviour. Annu. Rev. Pharmacol. Toxicol. 43, 261-284.

Ganapathy V. and Leibach F. H. (1994) Human placenta: a direct target for cocaine action. Placenta 15, 785-795.

Ganapathy, V., Prasad, P. D., Ganapathy, M. E. and Leibach, F. H. (1999) Drugs of abuse and placental transport. Adv. Drug Deliv. Rev. 38, 99-110.

German, J. B. and Walzem, R. L. (2000) The health benefits of wine. Annu. Rev. Nutr. 20, 561-593.

Grassl, S. M. (1998) Thiamine transport in human placental brush border membrane vesicles. Biochim. Biophys. Acta 1371, 213222.

Gujrati, V. R., Shanker, K., Vrat, S., Chandravati and Parmar S. S. (1996) Novel appearance of placental nuclear monoamine oxidase: biochemical and histochemical evidence for hyperserotonomic state in preeclampsia-eclampsia. Am. J. Obstet. Gynecol. 175, 1543-1550.

Halsted, C. H., Villanueva, J. A., Devlin, A. M. and Chandler, C. J. (2002) Metabolic interactions of alcohol and folate. J. Nutr. 32, 2367-2372.

Hoyumpa, A. M. Jr, Breen, K. J., Schenker, S. and Wilson, F. A. (1975) Thiamine transport across the rat intestine. II. Effect of ethanol. J. Lab. Clin. Med. 86, 803-816.

Hoyumpa, A. M. Jr, Nichols, S., Henderson, G. I. and Schenker, S. (1978) Intestinal thiamin transport: effect of chronic ethanol administration in rats. Am. J. Clin. Nutr. 31, 938-945.

Jayanthi, L. D., Ramamoorthy, S., Mahesh, V. B., Leibach, F. H. and Ganapathy, V. (1994) Calmodulin-dependent regulation of the catalytic function of the human serotonin transporter in placental choriocarcinoma cells. J. Biol. Chem. 269, 1442414429.

Keating, E., Lemos, C., Monteiro, R., Azevedo, I. and Martel, F. (2004) The effect of a series of organic cations upon the plasmalemmal serotonin transporter, SERT. Life Sci. 76, 103119.

Labay, V., Raz, T., Baron, D., Mandel, H., Williams, H., Barrett, T. et al. (1999) Mutations in SLC19A2 cause thiamine-response megaloblastic anaemia associated with diabetes mellitus and deafness. Nat. Genet. 22, 300-304.

Lemos, C., Calhau, C., Martel, F. and Azevedo, I. (2004) Intestinal thiamine uptake: characterization and nutritional modulation. FASEB J. 18, 708.

Lemos, C., Calhau, C., Martel, F. and Azevedo, I. (2005) Intestinal folate uptake: nutritional modulation. FASEB J. 19, 749.

Levin, S. W., Roecklein, B. A. and Mukherjee, A. B. (1985) Intrauterine growth retardation caused by dietary biotin and thiamine deficiency in the rat. Res. Exp. Med. (Berl) 185, 375381.

Liu, F., Soares, M. J. and Audus, K. L. (1997) Permeability properties of monolayers of the human trophoblast cell line BeWo. Am. J. Physiol. 273, 1596-1604.

Middleton, Jr E., Kandaswami, C. and Theoharides, T. C. (2000) The effects of plant flavonoids on mammalian cells: implication for inflammation, heart disease, and cancer. Pharmacol. Rev. 52, 673-751.

Moe, A. J., Furesz, T. C. and Smith, C. H. (1994) Functional characterization of L-alanine transport in a placental choriocarcinoma cell line (BeWo). Placenta 15, 797-802. 
Monteiro, R., Calhau, C., Martel, F., Guedes de Pinho, P. and Azevedo, I. (2005) Intestinal uptake of $\mathrm{MPP}^{+}$is differently affected by red and white wine. Life Sci. 76, 2483-2496.

Motulsky, H. J., Spannard, P. and Neubig, R. (1994) Graphpad Prism, version 1.0, Graphpad Prism Software, San Diego, USA.

Nehlig, A. and Debry, G. (1994) Consequences on the newborn of chronic maternal consumption of coffee during gestation and lactation: a review. J. Am. Coll. Nutr. 13, 6-21.

Nguyen, T. T., Tseng, Y. T., McGonnigal, B., Stabila, J. P., Worrell, L. A., Saha, S. and Padbury, J. F. (1999) Placental biogenic amine transporters: in vivo function, regulation and pathobiological significance. Placenta 20, 3-11.

Prasad, P. D., Hoffmans, B. J., Moe, A. J., Smith, C. H., Leibach, F. H. and Ganapathy, V. (1996) Functional expression of the plasma membrane serotonin transporter but not the vesicular monoamine transporter in human placental trophoblasts and choriocarcinoma cells. Placenta 17, 201-207.

Ramamoorthy, S., Bauman, A. L., Moore, K. R., Han, H., YangFen, T., Chang, A. S., et al. (1993) Antidepressant and cocaine-sensitive human serotonin transporter: molecular cloning, expression, and chromosomal localization. Proc. Natl.. Acad. Sci. USA 90, 2542-2546.

Rama Sastry, B. V. (1999) Techniques to study human placental transport. Adv. Drug Deliv. Rev. 38, 17-39.

Rindi, G. and Laforenza, U. (2000) Thiamine intestinal transport and related issues: recent aspects. Proc. Soc. Exp. Biol. Med. 224, 246-255.

Said, H. M., Ortiz, A., Kumar, C. K., Chatterjee, N., Dudeja, P. K. and Rubin, S. (1999) Transport of thiamine in human intestine: mechanism and regulation in intestinal epithelial cell model Caco-2. Am. J. Physiol. 277, 645-651.

Said, H. M., Ortiz, A., Subramanian, V. S., Neufeld, E. J., Moyer, M. P. and Dudeja, P. K. (2001) Mechanism of thiamine uptake by human colonocytes: studies with cultured colonic epithelial cell line NCM460. Am. J. Physiol. 281, 144-150.

Said, H. M., Reidling, J. C. and Ortiz, A. (2002) Cellular and molecular aspects of thiamin uptake by human liver cells: studies with cultured HepG2 cells. Biochim. Biophys. Acta 1567, 106-112.

Schenker, S., Johnson, R. F., Hoyumpa, A. M. and Henderson, G. I. (1990) Thiamine-transfer by human placenta: normal transport and effects of ethanol. J. Lab. Clin. Med. 116, 106115.

Singleton, C. K. and Martin, P. R. (2001) Molecular mechanisms of thiamine utilization. Curr. Mol. Med. 1, 197-207.

Stevens, J. F. and Page, J. E. (2004) Xanthohumol and related prenylflavonoids from hops and beer: to your good health! Phytochemistry 65, 1317-1330.

Sun, A. Y., Simonyi, A. and Sun, G. Y. (2002) The "French Paradox" and beyond: neuroprotective effects of polyphenols. Free Radic. Biol. Med. 32, 314-318.

Tanphaichitr, V. (1999) Thiamin; in Modern Nutrition in Health and Disease, Shils, M. E., Olson, J. A., Shike, M. and Ross, A. H. (eds.), pp. 381-389, Lippincott, Williams \& Wilkins, UK.

Thomson, A. D. (2000) Mechanisms of vitamin deficiency in chronic alcohol misusers and the development of the WernickeKorsakoff syndrome. Alcohol Alcohol 35, 2-7.

van den Berg, H., van der Gaag, M. and Hendriks, H. (2002) Influence of lifestyle on vitamin bioavailability. Int. J. Vitam. Nutr. Res. 72, 53-59.

Wade, P. R., Chen, J., Jaffe, B., Kassem, I. S., Blakely, R. D. and Gershon, M. D. (1996) Localization and function of a 5-HT transporter in crypt epithelia of the gastrointestinal tract. $J$. Neurosci. 16, 2352-2364.

Worthington-Roberts, B. S. (1999) Nutrition; in Cherry and Merkatz's Complications of Pregnancy, Cohen, W. R., Cherry, S. H. and Merkatz, I. R. (eds.), Lippincott, Williams \& Wilkins, UK. 